\title{
Involvement of epigenetic modification of $T E R T$ promoter in response to all-trans retinoic acid in ovarian cancer cell lines
}

\author{
Lorena Losi ${ }^{*}$, Angela Lauriola ${ }^{1,2}$, Erica Tazzioli ${ }^{1,3}$, Gaia Gozzi ${ }^{1}$, Letizia Scurani ${ }^{1}$, Domenico D'Arca ${ }^{2}$ and \\ Jean Benhattar ${ }^{3,4^{*}}$
}

\begin{abstract}
Background: All-trans retinoic acid (ATRA) is currently being used to treat hematological malignancies, given the ability to inhibit cell proliferation. This effect seems to be related to epigenetic changes of the TERT (Telomerase Reverse Transcriptase) promoter. When hypomethylated, ATRA-inducible TERT repressors can bind the promoter, repressing transcription of TERT, the rate-limiting component of telomerase. Ovarian carcinomas are heterogeneous tumors characterized by several aberrantly methylated genes among which is TERT. We recently found a hypomethylation of TERT promoter in about one third of serous carcinoma, the most lethal histotype. Our aim was to investigate the potential role of ATRA as an anticancer drug in a sub-group of ovarian carcinoma where the TERT promoter was hypomethylated.
\end{abstract}

Methods: The potential antiproliferative and cytotoxic effect of ATRA was investigated in seven serous ovarian carcinoma and one teratocarcinoma cell lines and the results were compared to the methylation status of their TERT promoter.

Results: The serous ovarian carcinoma cell line OVCAR3, harboring a hypomethylated TERT promoter, was the best and fastest responder. PA1 and SKOV3, two cell lines with an intermediate methylated promoter, revealed a weaker and delayed response. On the contrary, the other 5 cell lines with a highly methylated promoter did not respond to ATRA, indicative of ATRA-resistant cells.

Conclusions: Our results demonstrate an inverse correlation between the methylation level of TERT promoter and ATRA efficacy in ovarian carcinoma cell lines. Although these results are preliminary, ATRA treatment could become a new powerful, personalized therapy in serous ovarian carcinoma patients, but only in those with tumors harboring a hypomethylated TERT promoter.

Keywords: Ovarian cancer, serous ovarian carcinoma, ATRA, TERT, Telomerase, DNA methylation, Cell lines

\section{Introduction}

Retinoids are a class of compounds that are structurally associated to vitamin A. Experimental animal models, cellular models, epidemiological data and clinical trials provide a strong rationale for the use of retinoids in cancer therapy and prevention [1]. Alltrans retinoic acid (ATRA) is the most abundant

\footnotetext{
* Correspondence: lorena.losi@unimore.it; jean.benhattar@aurigen.ch 'Department of Life Sciences, Unit of Pathology, University of Modena and Reggio Emilia, Largo del Pozzo 71, 41124 Modena, Italy

${ }^{3}$ Institute of Pathology, Lausanne University Hospital, Lausanne, Switzerland Full list of author information is available at the end of the article
}

natural retinoid. The most effective clinical practice in human disease was demonstrated in acute promyelocytic leukemia where ATRA induces differentiation of the leukemic promyelocytes into granulocytes [2, 3]. ATRA and other retinoids have also been found to be effective in other hematological malignancies, but also in the treatment or in clinical trials of several types of solid cancers, such as thyroid [4], prostate [5], and breast [6]. ATRA causes cell cycle arrest at G1 phase and inhibits cell proliferation [2]. Although the mechanisms of the anti-cancer effects of retinoids are not fully understood, it is likely that

(c) The Author(s). 2019 Open Access This article is distributed under the terms of the Creative Commons Attribution 4.0 International License (http://creativecommons.org/licenses/by/4.0/), which permits unrestricted use, distribution, and reproduction in any medium, provided you give appropriate credit to the original author(s) and the source, provide a link to the Creative Commons license, and indicate if changes were made. The Creative Commons Public Domain Dedication waiver (http://creativecommons.org/publicdomain/zero/1.0/) applies to the data made available in this article, unless otherwise stated. 
they are due to the ability to inhibit cell proliferation and induce apoptosis which may be a result of telomerase inhibition [7-11].

The finding that most tumors express telomerase activity has led to an exponential growth of research to discover the role and regulation of this enzyme because the activation of telomerase is a critical step in carcinogenesis and cellular immortalization [12, 13]. The main gene responsible of telomerase activity is TERT (Telomerase Reverse Transcriptase). This gene codes for the catalytic subunit of telomerase enzyme liable to elongation of telomeres in up to $95 \%$ of malignant tumors [14]. TERT transcription leads to telomerase activity, and is an important factor linked to proliferation, differentiation and senescence. It is not found in the majority of somatic cells, while it is expressed in the proliferative cells such as germ cells, stem cells, and in the majority of tumors [12, 15]. One of the possible adjustments of TERT is at its promoter level. The TERT promoter is in a dense CG-rich CpG-island, indicating a role for methylation in the regulation of TERT expression [16]. TERT promoter hypermethylation is very common in many cancers contrarily to normal cells, and a positive correlation was found between TERT methylation and TERT expression, especially in epithelial tumors [1719]. The apparent opposition to the classic model of regulation of gene expression by DNA methylation was explained by the observation that methylation plays a dual role for TERT promoter. TERT methylation prevents the binding and thus the repressive effect of CTCF, whereas a small hypomethylated region around the transcription start site allows a weak transcription of TERT, despite the hypermethylation of the border regions $[20,21]$.

The study of Azouz et al. [22] demonstrated that ATRA-inducible TERT repressors bind to the promoter of TERT, only when this promoter is hypomethylated, blocking transcription of the gene and, consequently, causing malfunction of telomerase. On the one hand, TERT is generally hypomethylated in a great majority of lymphoproliferative tumors [23] where ATRA is effective, on the other hand, TERT is hypermethylated in a majority of epithelial tumors [18] where ATRA is generally ineffective. Ovarian carcinomas are heterogeneous tumors with different morphological, molecular and clinical features and are characterized by several aberrantly methylated genes, among which TERT [24-28]. Nevertheless, we recently found a hypomethylation of TERT promoter in about one third of serous carcinomas [29], the most lethal histotype of ovarian cancer.

Most of the advanced ovarian cancer patients respond well to first line of chemotherapy based on carboplatin and taxane. Despite this high initial response rate, a majority of patients relapse and die of the disease [30]. The response to second line of chemotherapy is much lower [31]. To overcome resistance, it is important to search for additional drugs that could be used in combination to increase the anticancer effect.

The aim of this study was to predict the role of ATRA as a potential anticancer drug in the sub-group of ovarian carcinomas in which the TERT promoter is hypomethylated. Several ovarian carcinoma cell lines were treated with ATRA, and we determined whether a correlation between the antiproliferative and cytotoxic effects of all-trans retinoid acid and the methylation status of TERT promoter in these cell lines exists.

\section{Results}

\section{ATRA treatment and cellular growth}

To evaluate the effective contribution of ATRA treatment on cell growth in ovarian cancer cell lines, we performed cell counts of control and treated cells on days 3, 5 and 7 after treatment. The selected concentration of $1 \mu \mathrm{M}$ of ATRA was used for this study. This concentration was chosen because it has been shown the strongest support by patients according to the pharmacokinetic studies, which permit to avoid the severe toxicity of the drug [32]. The graphs of cellular growth after ATRA treatment are shown in Fig. 1. As a control (CTRL), we considered the cell lines treated only with ethanol, the solvent for ATRA. Together with ovarian carcinoma cell lines, we considered a colorectal carcinoma (CRC) cell line not sensitive to $1 \mu \mathrm{M}$ of ATRA, HT29 [33]. According to the effect of ATRA on the last day of treatment (day 7), we highlighted three cell lines with an ATRAinhibitor effect on the cell growth.

The inhibitory action of ATRA on the cell growth was a rapid and clearly marked process for the OVCAR3 cell line $(\mathrm{p}<0.05)$. A substantial diminution of ATRA-treated cell growth was observed on day 3 , increasing up to day 7. PA1 and SKOV3 cells showed a cell growth diminution on day 7 , whereas they did not show numeric difference on days 3 and 5. There were no changes in growth curves between ATRA-treated and control cells in any of the other ovarian cancer cell lines-A2780, CAOV3, OVMZ6, OVMZ36, OVMZ37 and SKOV3-, and in the HT29 CRC cell line.

\section{ATRA treatment and cell viability}

The effect of ATRA treatment on cell viability was measured using the MTT colorimetric assay. The ATRA-insensitive HT29 cells showed, as expected, a cell viability almost unchanged. In regard to the ovarian cells, the results of the MTT assay were in complete agreement with those previously obtained 


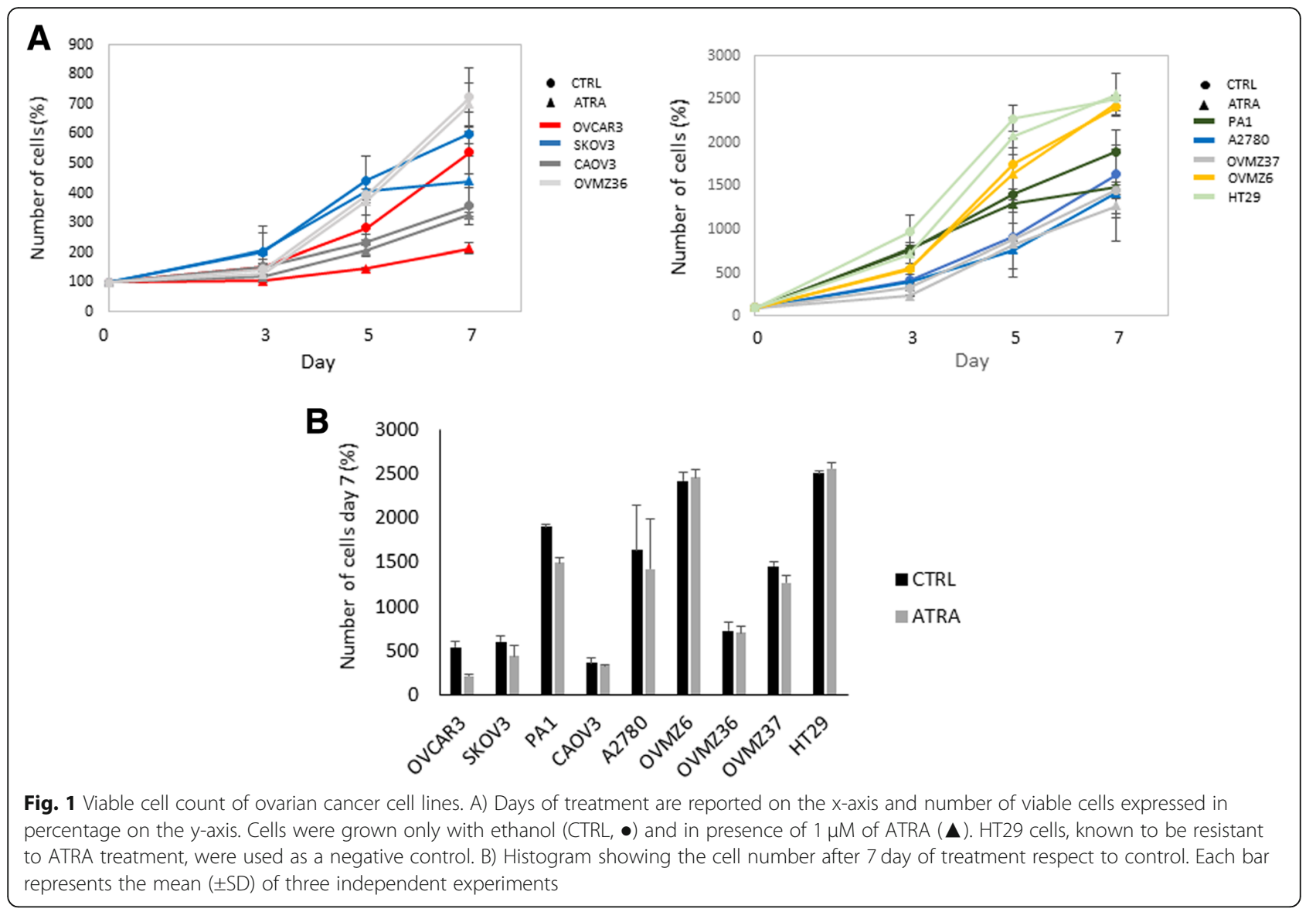

for the cell growth. For the same 3 cell lines (OVCAR3, PA1 and SKOV3), we observed that the percentage of viable cells decreased at the end of ATRA treatment $(p<0.05$ for OVCAR3), (Fig. 2). In OVCAR3, the percentage of cell viability decreased significantly already from day 5 of treatment while for the other two cells lines, the decrease in viability was only observed on day 7 . Concerning the other five ovarian cell lines, no decrease in cell viability was noticed. Surprisingly, we observed an increase in A2780 cell viability at the end of ATRA treatment.

\section{ATRA treatment and TERT expression}

TERT gene expression quantification was obtained with real-time PCR on cDNA previously retro-transcripted. Quantitative variation of TERT expression was performed on cell samples collected on days 3 and 7 of ATRA treatment. In ATRA treated cells, a decreased TERT expression was noticed on day 7 at the end of the treatment for OVCAR3, PA1, and SKOV3 (Fig. 3). These 3 cell lines have already shown a decrease in cell growth and cell viability after ATRA treatment. In contrast, the other 5 ovarian cell lines and the colon cell line, showed an increase in TERT expression after ATRA treatment.

\section{TERT promoter methylation}

In order to evaluate the methylation level of TERT promoter and search for a correlation with cell count, cell viability, and TERT expression, we analyzed the pretreatment ovarian cell lines A2780, CAOV3, OVMZ6, OVMZ36, OVMZ37, SKOV3, and HT29 CRC. Fig. 4 depicts the results of the pyrosequencing reporting the percentage of methylation (part A) and their localization (part B) for each of the 14 CpG sites analyzed. Significant variability on methylation percentage for each $\mathrm{CpG}$ site of the TERT promoter region was observed in all the analyzed cell lines. According to the TERT methylation status, we were able to identify 3 groups of cell lines.

OVCAR3 showed the lowest percentage of methylation among all the analyzed cell lines. The distribution of methylation between the CpG sites varied from a minimum of $13 \%$ to a maximum of $42 \%$, with an average DNA methylation level of $27 \%$.

PA1 and SKOV3 cell lines showed an intermediate level of methylation, especially for the first seven CpG sites, with levels of methylation that varied between 44 and $70 \%$, and an average methylation level of $55 \%$ for PA1 and 59\% for SKOV3; a unique peak of high methylation, 65 and 70\% for PA1 and SKOV3 was observed at CpG position 10 (Fig. 4). 


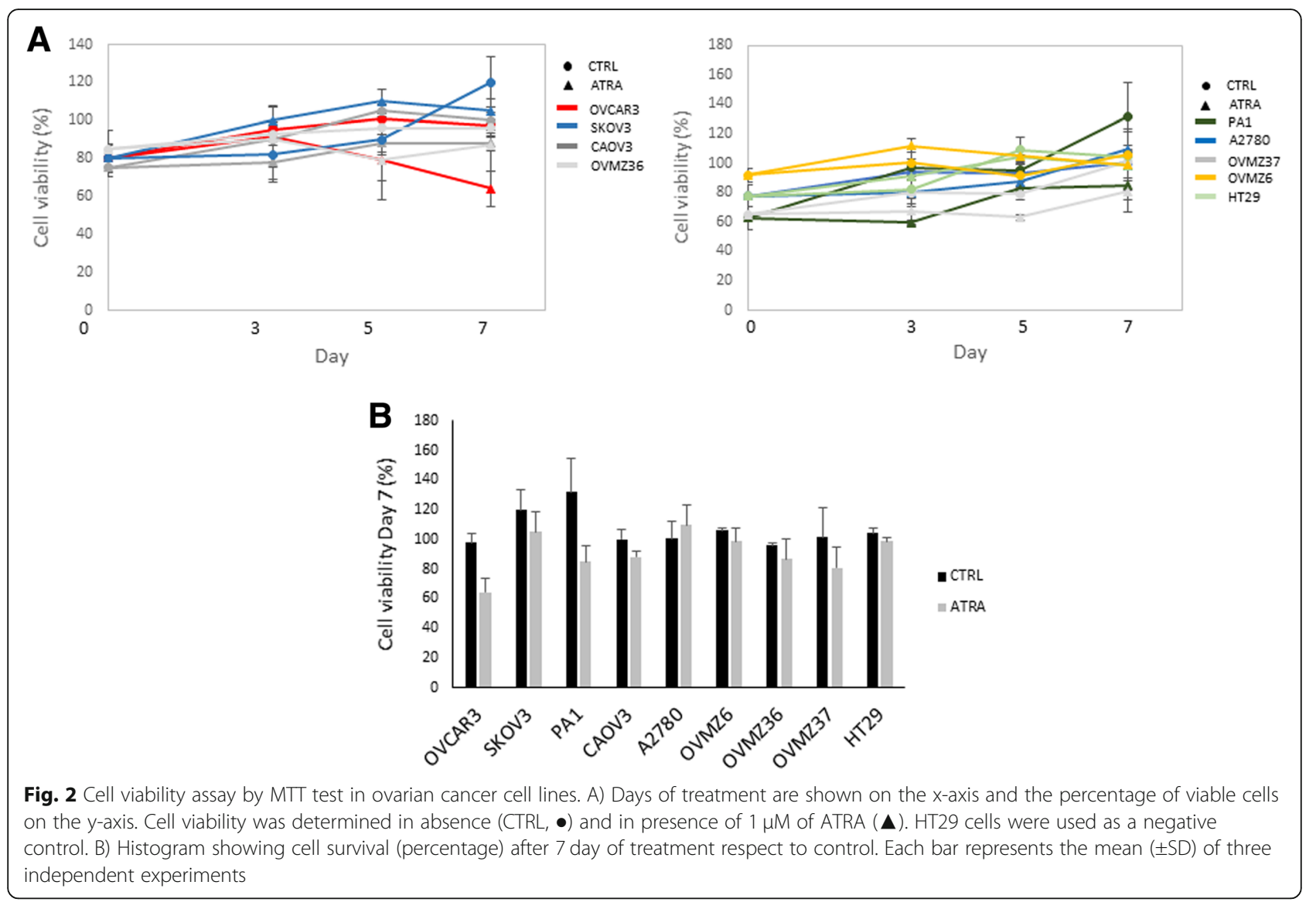

Considering the first seven CpG sites, we observed a high methylation percentage that ranged from 72 to $100 \%$ in A2780, CAOV3, OVMZ6, OVMZ36 and OVMZ37 with an average methylation level varying from 83 to $92 \%$. A high methylation level was observed in the remaining seven CpG sites with percentage from 72 to $98 \%$ for A2780 and OVMZ37, while for CAOV3, OVMZ6 and OVMZ36 levels of methylation were more heterogeneous and ranged from a minimum of $51 \%$ to a maximum of $99 \%$.

\section{TERT methylation level and response to ATRA}

The average methylation level of the analyzed TERT promoter region can be divided into 3 groups: low; for an average methylation lower than $30 \%$, intermediate; for a methylation ranged from 30 to $70 \%$, and high; for a methylation up to $70 \%$. Therefore, TERT promoter methylation was low for OVCAR3, intermediate for PA1 and SKOV3 and high for the other cell lines.

ATRA treatment had an effect on cell growth, cell viability, and TERT expression in the three ovarian cell lines with a low or an intermediate level of TERT methylation (Table 1). As it can be shown in Figs. 1, 2, and 3, the effect of ATRA was more pronounced and occurred earlier in OVCAR3, the cell line with the lowest level of TERT promoter methylation. By contrast, at the end of ATRA treatment (day 7) no effect on the five ovarian cell lines with a high level of TERT methylation was observed (Table 1).

\section{Discussion}

In this study, we examined the effect of ATRA in ovarian cancer cell lines in order to evaluate whether epigenetic modification of TERT promoter gene can be involved in different cellular response to retinoid treatment. An inverse correlation between the level of TERT promoter methylation and ATRA efficacy was noticed. The serous ovarian carcinoma cell line OVCAR3, which harbored a hypomethylated promoter, was the strongest and fastest respondence to ATRA treatment. The two cell lines with an intermediate methylated promoter, PA1 and SKOV3, also demonstrated a response though weaker and time delayed. On the contrary, the other ovarian cancer cell lines showed a heavily methylated promoter and none responded to ATRA.

Therefore, a strong correlation was observed between TERT promoter methylation levels and the results obtained by cell growth, cell viability, and TERT 

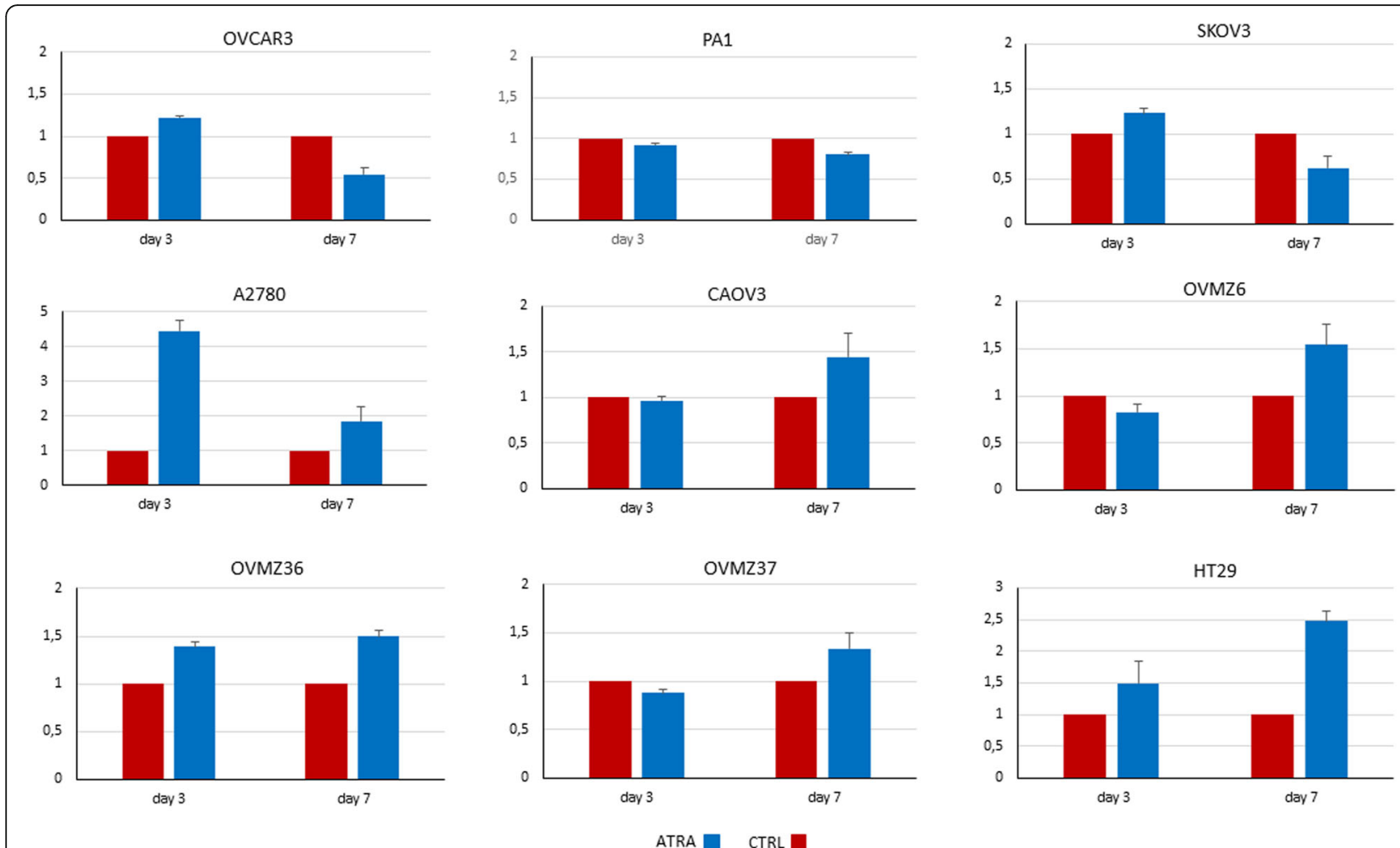

Fig. 3 TERT expression by real time PCR in ovarian cancer and HT29 cell lines. Days of treatment are shown on the x-axis and TERT expression on the $y$-axis. TERT expression was determined in absence (red bars; CTRL) and in presence (blue bars) of $1 \mu \mathrm{M}$ ATRA. The last cell line HT29 was used as a negative control. Each bar represents the mean $( \pm S D)$ of three independent experiments

gene expression after ATRA treatment. Low levels of promoter methylation allow an ATRA inhibitory action on TERT expression and cell growth, as observed in the serous ovarian carcinoma cell line OVCAR3. Although the mechanisms of the anti-cancer effects of retinoids are not fully understood, it is likely that they are due to the ability to inhibit cell proliferation and induce apoptosis, which may be a result of telomerase inhibition [7-11,34]. Indeed, this mechanism was proposed by Love et al., 2008 in human leukemia cells in which ATRA treatment reduced cellular proliferation and induced apoptosis in the HL60 cells, only after inhibition of telomerase activity due to the down-regulation of TERT transcription [9]. The authors proposed that the epigenetic changes in the TERT promoter represent a stable locking mechanism in the retinoid-induced suppression of telomerase activity. Later, the study of Azouz et al. demonstrated in acute promielocytic leukemia cell line that ATRAinducible TERT repressors bind to the promoter of TERT when it is not methylated, blocking transcription of the gene and, consequently, causing malfunction of telomerase [22].

Most ovarian cancer cells are sensitive to platinum, which is especially the case of the four cell lines investigated in this study, A2780, CAOV3, SKOV3 and OVCAR3 [35, 36]. However, these four cell lines revealed different responses to ATRA and varying levels of TERT promoter methylation. Therefore, we can conclude that there are no correlations between sensitivity to platinum, ATRA response, and the status of TERT promoter methylation in ovarian cancer cell lines.

Our results are in agreement with previous findings obtained in leukemia cell lines suggesting that epigenetic mechanism can be responsible of different ATRA response and highlights that a low methylation level of TERT promoter correlates with drug efficacy. By contrast, the drug was not active in cell lines with a high hypermethylation of TERT. Furthermore, our data confirms that telomerase activity, through TERT promoter methylation, plays an important role in cell immortalization and continues to be subject for future studies and applications in molecular therapies. In a parallel project, we analyzed neoplastic tissue of serous ovarian carcinoma patients and observed TERT promoter hypomethylation in about one third of cases [29]. For this reason, we expected to find more cell lines with low methylation levels, not only one. Moreover, CAOV3 cell line, differently from us, was found 


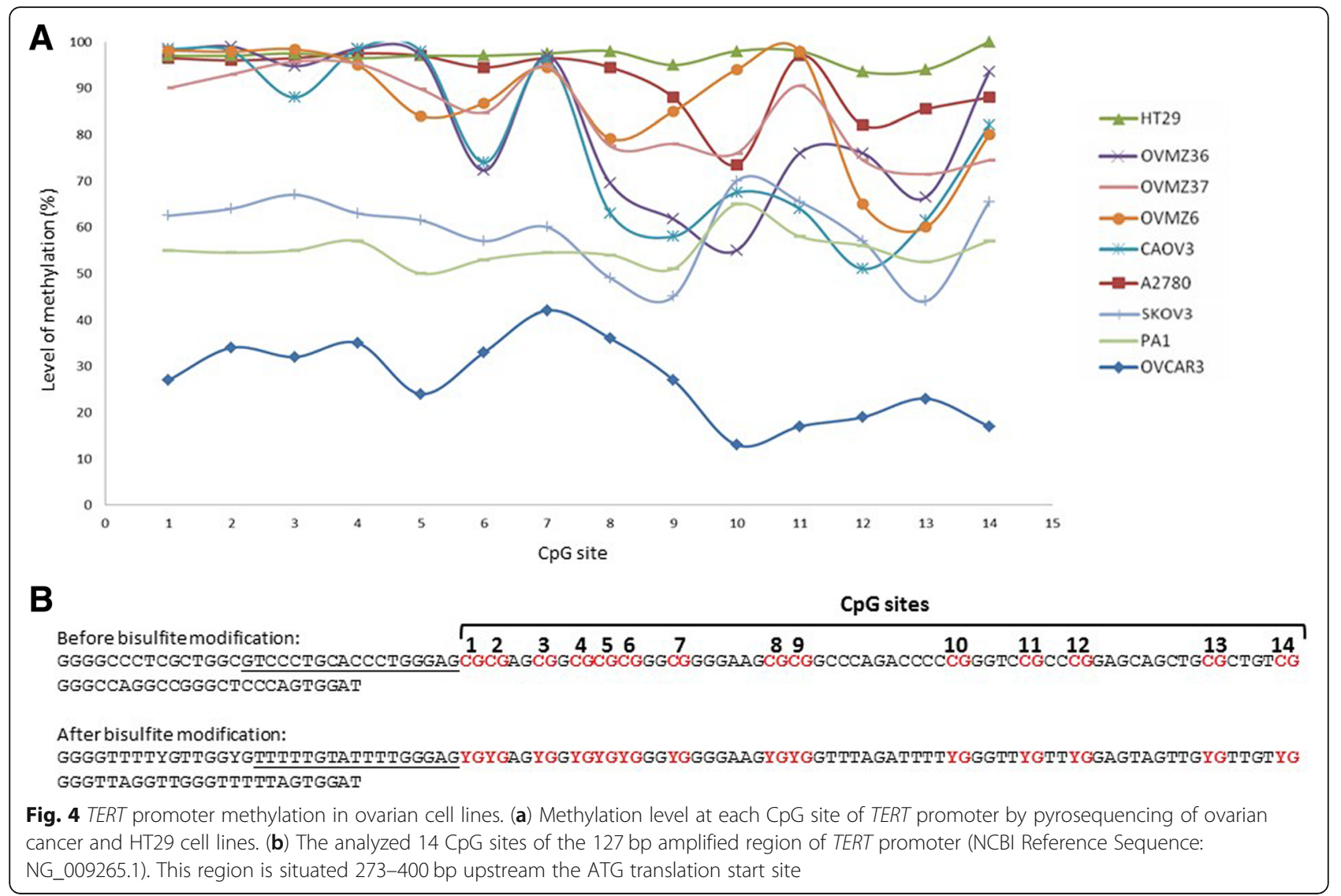

responsive to ATRA treatment in previous works of the same group [37, 38]. As already well described, an explanation can be due to the changes that occur during the culture of cells prolonged for a long time [39, 40]; specific clones characterized by higher methylation level can be selected. Wu et al. (1997), showed different responsiveness from clone to clone [37]. On the other hand, we tried to use different cell lines without TERT methylation, but had several

Table 1 Correlation between level of TERT promoter methylation and response to ATRA at the end of treatment (day 7)

\begin{tabular}{lllll}
\hline Cell line & TERT & \multicolumn{3}{l}{ ATRA treatment } \\
\cline { 3 - 5 } & methylation & Cellular growth & Cell viability & TERT expression \\
\hline OVCAR3 & Low & $\searrow$ & $\searrow$ & $\searrow$ \\
PAl1 & Intermediate & $\searrow$ & $\searrow$ & $\searrow$ \\
SKOV3 & Intermediate & $\searrow$ & $\searrow$ & $\searrow$ \\
A2780 & High & $\rightarrow$ & $\rightarrow$ & $\nearrow$ \\
CAOV3 & High & $\rightarrow$ & $\rightarrow$ & $\nearrow$ \\
OVMZ6 & High & $\rightarrow$ & $\rightarrow$ & $\nearrow$ \\
OVMZ36 & High & $\rightarrow$ & $\rightarrow$ & $\nearrow$ \\
OVMZ37 & High & $\rightarrow$ & $\rightarrow$ & $\nearrow$ \\
\hline
\end{tabular}

difficulties with their culture because they were inclined to differentiate and die off quickly.

\section{Conclusions}

Our study demonstrated the importance of TERT epigenetic modification in the cellular response of retinoid treatment in ovarian cancer cell lines. A hypomethylation of the TERT promoter, even partial, will lead to a response to ATRA treatment, whereas a complete hypermethylation will lead to a total absence of ATRA efficacy. If confirmed by further biological and clinical studies, ATRA could be used in combination with platinum therapy in patients with TERT hypomethylated ovarian carcinomas, representing a further example of precision medicine.

\section{Materials and methods \\ Cell culture}

Human serous ovarian carcinoma cell lines (A2780, CAOV3, OVCAR3, OVMZ6, OVMZ36, OVMZ37, SKOV3), ovarian teratocarcinoma cell line (PA1) and human colorectal carcinoma (CRC) cell line HT29 were obtained from the Department of Molecular Pathology (CHUV, Lausanne, Switzerland). A2780, CAOV3, SKOV3 


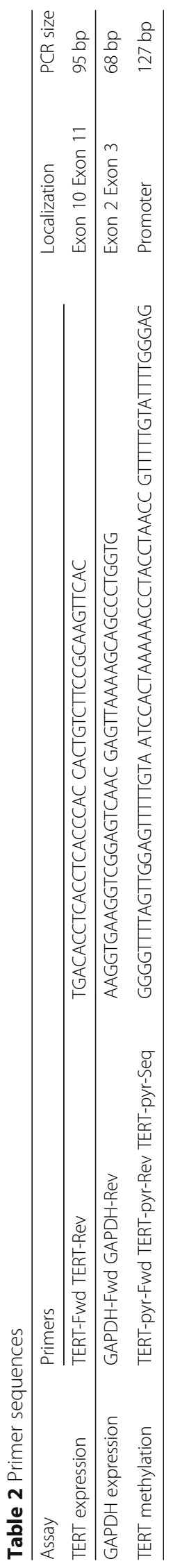


and OVCAR3 were reported to be sensitive to very sensitive to platinum based chemotherapy [35].

Cells were cultured in Roswell Park Memorial Institute Medium (RPMI 1640) + L-glutamine supplemented with 10\% Fetal Bovine Serum (FBS), 1\% PSF (Penicillin/ streptomycin + Fungizone - Amphotericin B) and in Dulbecco's Modified Eagle Medium $+4.5 \mathrm{~g} / \mathrm{l} \mathrm{D}$-glucose + Pyruvate (DMEM), supplemented with 10\% Fetal Bovine Serum (FBS), 1\% PSF. Cells were maintained in a humidified atmosphere at $37{ }^{\circ} \mathrm{C}$ and in $5 \% \mathrm{CO} 2$. Cell lines were stored in liquid nitrogen with 5\% DMSO. All products were from ThermoFisher Scientific. All cell lines tested negative for mycoplasma contamination using MycoAlertTM Mycoplasma Detection Kit, Lonza, catalog number LT07-318.

\section{ATRA treatment}

All-Trans Retinoic Acid (ATRA) powder was purchased from Sigma Aldrich. ATRA was dissolved in ethanol at final concentration of $5 \mathrm{mM}$ and stored at $-20^{\circ} \mathrm{C} .2 \times 10^{5}$ cells were seeded in six well plates. After $24 \mathrm{~h}$, the cells were treated for 7 days with medium containing ATRA with a final concentration of $1 \mu \mathrm{M}$. Cell medium was replaced every $48 \mathrm{~h}$. Cells were collected on day 3, 5 and 7 after ATRA treatment, counted using a Neubauer hematocytometer, and cell pellets were frozen for subsequent analyses. As a control, we used cell lines treated only with ethanol, the solvent for ATRA. Experiments were performed in triplicate.

\section{Cell viability assay}

Cell viability was measured using the 3-(4,5-dimethylthiazol-2-yl)-2,5-diphenyltetrazolium bromide (MTT) assay (Alfa Aesar). Cells were plated in 96-well plates and treated with ATRA as described above. After incubation for the indicated time intervals, $0.5 \mathrm{mg} / \mathrm{mL}$ of MTT was added to each well for $4 \mathrm{~h}$. The blue MTT formazan precipitate was then dissolved in $200 \mu \mathrm{L}$ of an Isopropanol- $\mathrm{HCl}$ solution. The absorbance at $540 \mathrm{~nm}$ was measured by Synergy ${ }^{\mathrm{Tm}} \mathrm{Mx}$ spectrophotometer (BioTek). Gen ${ }^{\mathrm{mm}}$ software (BioTek) was used for the analysis.

\section{Real-time PCR evaluation of TERT mRNA}

RNA extraction was performed by using RNeasy Mini Kit (Qiagen) according to the manufacturer's instructions. Subsequently, the reverse transcription-polymerase chain reaction (RT-PCR) was performed with $2 \mu$ g of total RNA using SuperScript ${ }^{\text {tm }}$ III Reverse Transcriptase (ThermoFisher Scientific). The profile used for the reaction was: $25^{\circ} \mathrm{C}$ for $5 \mathrm{~min}, 50^{\circ} \mathrm{C}$ for $50 \mathrm{~min}$ and $70^{\circ} \mathrm{C}$ for $15 \mathrm{~min}$. Next, the real-time PCR was performed with $2 \mu \mathrm{L}$ of cDNA using a Platinum ${ }^{\circ}$ Taq DNA polymerase (ThermoFisher Scientific) and a mix of TERT and GAPDH primers
(Table 2). Samples were amplified by 45 cycles at $95^{\circ} \mathrm{C}$ for $10 \mathrm{~s}, 58^{\circ} \mathrm{C}$ for $10 \mathrm{~s}$, and $72{ }^{\circ} \mathrm{C}$ for $15 \mathrm{~s}$, in a Rotor-Gene 6000 and data were analyzed with Rotor-Gene Q Series Software (Qiagen). For each sample, three replicates were acquired. TERT mRNA expression was normalized with $G A P D H$ as an internal control.

\section{TERT methylation analysis by bisulfite pyrosequencing}

DNA was extracted from cell lines using DNeasy Blood \& Tissue Kit as descripted by the manufacturer (Qiagen). Extracted DNAs (500 ng) were bisulfite modified using EpiTect Fast DNA kit according to the manufacturer's protocol (Qiagen). Briefly, a total of DNA was denaturated with sodium hydroxide and modified with sodium bisulfite. DNA samples were then purified using MiniElute DNA spin columns and elution of converted DNA was performed with $20 \mu \mathrm{L}$ elution buffer.

The eluted, bisulfite converted DNA was used for pyrosequencing PCR amplification. Bisulfite-PCRPyrosequencing was performed in $20 \mu \mathrm{L}$ reaction mixture containing $3 \mu \mathrm{L}$ of converted DNA and forward and biotinylated reverse primers (TERT-pyr-Fwd and TERT-pyr-Rev, Table 2). The PCR conditions were as follows: after an initial 5-min denaturation step at $95^{\circ} \mathrm{C}, 40$ amplification cycles were performed, each consisting of denaturation $\left(15 \mathrm{~s}\right.$ at $\left.95^{\circ} \mathrm{C}\right)$, annealing $\left(15 \mathrm{~s}\right.$ at $\left.60^{\circ} \mathrm{C}\right)$ and elongation $\left(30 \mathrm{~s}\right.$ at $\left.72^{\circ} \mathrm{C}\right)$ steps followed by a final incubation at $72{ }^{\circ} \mathrm{C}$ for $5 \mathrm{~min}$. The expected PCR product size was $127 \mathrm{bp}$. Ten $\mu \mathrm{L}$ of biotinylated PCR product was immortalized on streptavidin-coated sepharose high-performance beads (GE Healthcare Bio-sciences $\mathrm{AB}$ ) and processed to obtain a single-strand DNA using the PyroMark Vacuum Prep Workstation (Qiagen) according to the manufacturer's instruction. The template was incubated with $3 \mu \mathrm{mol} / \mathrm{L}$ TERT-pyr-Seq sequencing primer at $80^{\circ} \mathrm{C}$ for $2 \mathrm{~min}$. The pyrosequencing reaction of the complementary strand was automatically performed on PyroMark Q24 Advanced (Qiagen) using PyroGold reagents (Qiagen). As nucleotides were dispensed, a light signal was generated proportional to the amount of each incorporated nucleotide. The percentage of cytosine methylation for each CpG site within the analyzed region of the TERT promoter gene was calculated using the PyroMark Q24 Software (Qiagen) that allows the methylation analysis at each CpG site.

\section{Statistical analysis}

All assays were performed at least three times. The results were presented as mean $\pm \mathrm{SD}$. Statistical analysis was conducted by t-test. $P<0.05$ was considered significant. 


\section{Acknowledgements}

We thank Dr. Kevin Israel Munoz for the English revision of the manuscript.

\section{Authors' contributions}

$L L$ and JB conceived and designed the study. $L L, A L, E T, G G, L S, D D$ and $J B$ acquired, analyzed and interpreted the data. $\mathrm{LL}$ and JB wrote and revised the work for intellectual content and context. All authors read and approved the final manuscript.

\section{Funding}

This research did not receive any specific grant from funding agencies in the public, commercial, or not-for-profit sectors.

\section{Availability of data and materials}

All data generated or analyzed during this study are included in this published article.

\section{Ethics approval and consent to participate}

Not applicable.

\section{Consent for publication}

Not applicable.

\section{Competing interests}

The authors declare that they have no competing interests.

\section{Author details}

'Department of Life Sciences, Unit of Pathology, University of Modena and Reggio Emilia, Largo del Pozzo 71, 41124 Modena, Italy. ${ }^{2}$ Department of Biomedical, Metabolic and Neural Sciences, University of Modena and Reggio Emilia, Modena, Italy. Institute of Pathology, Lausanne University Hospital, Lausanne, Switzerland. ${ }^{4}$ Aurigen, Centre de Génétique et Pathologie, Avenue de Sévelin 18, 1004 Lausanne, Switzerland.

\section{Received: 11 February 2019 Accepted: 1 July 2019}

Published online: 10 July 2019

\section{References}

1. Dragnev KH, Rigas JR, Dmitrovsky E. The retinoids and cancer prevention mechanisms. Oncologist. 2000;5:361-8.

2. Bushue N, Wan YJ. Retinoid pathway and cancer therapeutics. Adv Drug Deliv Rev 2010; 62:1285-1298. https://doi:10.1016/j.addr.2010.07.003.

3. Adès L, Guerci A, Raffoux E, Sanz M, Chevallier P, Lapusan S, Recher C, Thomas X, Rayon C, Castaigne S, Tournilhac O, de Botton S, Ifrah N, et al. Very long-term outcome of acute promyelocytic leukemia after treatment with all-trans retinoic acid and chemotherapy: the European APL Group experience. Blood. 2010:115:1690-1696. https://doi:10.1182/blood-2009-07233387

4. Pak K, Shin S, Kim SJ, Kim IJ, Chang S, Koo P, Kwak J, Kim JH. Response of retinoic acid in patients with radioactive iodine-refractory thyroid Cancer: a meta-analysis. Oncol Res Treat 2018;41:100-104. https://doi:10.1159/ 000484206.

5. Pasquali D, Rossi V, Bellastella G, Bellastella A, Sinisi AA. Natural and synthetic retinoids in prostate cancer. Curr Pharm Des. 2006;12:1923-9.

6. Alsafadi S, Even C, Falet C, Goubar A, Commo F, Scott V, Quidville V, Albiges L, Dieci MV, Guegan J, Lazar V, Ahomadegbe JC, Delaloge S, André F. Retinoic acid receptor alpha amplifications and retinoic acid sensitivity in breast cancers. Clin Breast Cancer 2013;13:401-408. https://doi:10.1016/j.clbc. 2013.02.001.

7. Pendino F, Sahraoui T, Lanotte M, Ségal-Bendirdjian E. A novel mechanism of retinoic acid resistance in acute promyelocytic leukemia cells through a defective pathway in telomerase regulation. Leukemia. 2002;16:826-32.

8. Pendino F, Hillion J, Dudognon C, Delaunay J, Mourah S, Podgorniak MP, Lafon I, Chomienne C, Lanotte M, Dombret H, Rousselot P, SégalBendirdjian E. Telomerase targeting by retinoids in cells from patients with myeloid leukemias of various subtypes, not only APL. Leukemia. 2006;20: 599-603.

9. Love WK, Berletch JB, Andrews LG, Tollefsbol TO. Epigenetic regulation of telomerase in retinoid-induced differentiation of human leukemia cells. Int Oncol. 2008;32:625-31.
10. Phipps SM, Love WK, White T, Andrews LG, Tollefsbol TO. Retinoid-induced histone deacetylation inhibits telomerase activity in estrogen receptornegative breast cancer cells. Anticancer Res. 2009;29:4959-64.

11. Karabulut B, Karaca B, Varol U, Muslu U, Cakar B, Atmaca H, Kisim A Uzunoglu S, Uslu R. Enhancing cytotoxic and apoptotic effect in OVCAR-3 and MDAH-2774 cells with all-trans retinoic acid and zoledronic acid: a paradigm of synergistic molecular targeting treatment for ovarian cancer. J Exp Clin Cancer Res 2010;29:102. https://doi:10.1186/1756-9966-29-102.

12. Kim NW, Piatyszek MA, Prowse KR, Harley CB, West MD, Ho PL, Coviello GM, Wright WE, Weinrich SL, Shay JW. Specific association of human telomerase activity with immortal cells and cancer. Science. 1994;266:2011-5.

13. Meyerson M. Role of telomerase in normal and cancer cells. J Clin Oncol. 2000;18:2626-34.

14. Cong YS, Wen J, Bacchetti S. The human telomerase catalytic subunit hTERT: organization of the gene and characterization of the promoter. Hum Mol Genet. 1999:8:137-42.

15. Alberti L, Losi L, Leyvraz S, Benhattar J. Different effects of BORIS/CTCFL on Stemness gene expression, sphere formation and cell survival in epithelial Cancer stem cells. PLoS One 2015; 10:e0132977. https://doi:10.1016/j.bbrc 2016.09.049

16. Horikawa I, Cable PL, Afshari C, Barrett JC. Cloning and characterization of the promoter region of human telomerase reverse transcriptase gene. Cancer Res. 1999:59:826-30.

17. Devereux TR, Horikawa I, Anna CH, Annab LA, Afshari CA, Barrett JC. DNA methylation analysis of the promoter region of the human telomerase reverse transcriptase (hTERT) gene. Cancer Res. 1999;59:6087-90.

18. Guilleret I, Yan P, Grange F, Braunschweig R, Bosman FT, Benhattar J. Hypermethylation of the human telomerase catalytic subunit (hTERT) gene correlates with telomerase activity. Int J Cancer. 2002;101:335-41.

19. Guilleret I, Benhattar J. Unusual distribution of DNA methylation within the hTERT CPG island in tissues and cell lines. Biochem Biophys Res Commun. 2004;325:1037-43.

20. Renaud S, Loukinov D, Bosman FT, Lobanenkov V, Benhattar J. CTCF binds the proximal exonic region of hTERT and inhibits its transcription. Nucleic Acids Res. 2005;33:6850-60

21. Renaud S, Loukinov D, Abdullaev Z, Guilleret I, Bosman FT, Lobanenkov V, Benhattar J. Dual role of DNA methylation inside and outside of CTCFbinding regions in the transcriptional regulation of the telomerase hTERT gene. Nucleic Acids Res. 2007;35:1245-56

22. Azouz A, Wu YL, Hillion J, Tarkanyi I, Karniguian A, Aradi J, Lanotte M, Chen GQ, Chehna M, Ségal-Bendirdjian E. Epigenetic plasticity of hTERT gene promoter determines retinoid capacity to repress telomerase in maturationresistant acute promyelocytic leukemia cells. Leukemia. 2010;24: 613-622. https://doi:10.1038/leu.2009.283.

23. Bougel S, Renaud S, Braunschweig R, Loukinov D, Morse HC 3rd, Bosman FT, Lobanenkov $V$, Benhattar J. PAX5 activates the transcription of the human telomerase reverse transcriptase gene in B cells. J Pathol 2010;220:87-96. https://doi:10.1002/path.2620

24. Kurman RJ, Shih leM. Pathogenesis of ovarian cancer: lessons from morphology and molecular biology and their clinical implications. Int J Gynecol Pathol 2008;27:151-160. https://doi:10.1097/PGP.0b013e318161e4f5.

25. Makarla PB, Saboorian MH, Ashfaq R, Toyooka KO, Toyooka S, Minna JD, Gazdar AF, Schorge JO. Promoter hypermethylation profile of ovarian epithelial neoplasms. Clin Cancer Res. 2005;11:5365-9.

26. Gloss BS, Samimi G. Epigenetic biomarkers in epithelial ovarian cancer. Cancer Lett 2014;342:257-263. https://doi: 10.1016/j.canlet.2011.12.036.

27. Earp MA, Cunningham JM. DNA methylation changes in epithelial ovarian cancer histotypes. Genomics. 2015;106:311-321. https://doi: 10.1016/j.ygeno. 2015.09.001.

28. Gozzi G, Chelbi ST, Manni P, Alberti L, Fonda S, Saponaro S, Fabbiani L, Rivasi F, Benhattar J, Losi L. Promoter methylation and downregulated expression of the TBX15 gene in ovarian carcinoma. Oncol Lett. 2016;12: 2811-6.

29. Losi L, Fonda S, Saponaro S, Chelbi ST, Lancellotti C, Gozzi G, Alberti L, Fabbiani L, Botticelli L, Benhattar J. Distinct DNA methylation profiles in ovarian tumors: opportunities for novel biomarkers. Int J Mol Sci 2018; 19: E1559. https://doi:10.3390/ijms19061559.

30. Christie EL, Bowtell DDL. Acquired chemotherapy resistance in ovarian cancer. Ann Oncol. 2017;28(suppl_8):viii13-5.

31. Lheureux S, Gourley C, Vergote I, Oza AM. Epithelial ovarian cancer. Lancet. 2019; 393:1240-1253. doi: 10.1016/S0140-6736(18)32552-2. 
32. Adamson PC. (1996) all-trans-retinoic acid pharmacology and its impact on the treatment of acute promyelocytic leukemia. Oncologist. 1996;1:305-14.

33. Bartolini G, Ammar K, Mantovani B, Scanabissi F, Ferreri AM, Rocchi P, Orlandi M. Retinoids and cancer: antitumor effect of ATRA and of a new derivative of retinoic acid, IIF, on colon carcinoma cell lines $\mathrm{CaCo}-2$ and HT29. Anticancer Res. 2004;24:1779-84.

34. Purev E, Soprano DR, Soprano KJ. Effect of all-trans retinoic acid on telomerase activity in ovarian cancer cells. J Exp Clin Cancer Res. 2004;23: 309-16.

35. Beaufort CM, Helmijr JC, Piskorz AM, Hoogstraat M, Ruigrok-Ritstier K, Besselink N, Murtaza M, van IJcken WF, Heine AA, Smid M, Koudijs MJ, Brenton JD, Berns EM, Helleman J. Ovarian cancer cell line panel (OCCP): clinical importance of in vitro morphological subtypes. PLoS One 2014 Sep 17;9(9):e103988. doi: 10.1371/journal.pone.0103988. eCollection 2014.

36. Smith JA, Ngo H, Martin MC, Wolf JK. An evaluation of cytotoxicity of the taxane and platinum agents combination treatment in a panel of human ovarian carcinoma cell lines. Gynecol Oncol. 2005;98:141-5.

37. Wu S, Zhang ZP, Zhang D, Soprano DR, Soprano KJ. Reduction of both RAR and RXR levels is required to maximally alter sensitivity of CA-OV3 ovarian tumor cells to growth suppression by all-trans-retinoic acid. Exp Cell Res. 1997;237:118-26.

38. Radu M, Soprano DR, Soprano KJ. S10 phosphorylation of p27 mediates atRA induced growth arrest in ovarian carcinoma cell lines. J Cell Physiol 2008;217:558-568. https://doi:10.1002/jcp.21532.

39. Nestor CE, Ottaviano R, Reinhardt D, Cruickshanks HA, Mjoseng HK, McPherson RC, Lentini A, Thomson JP, Dunican DS, Pennings S, Anderton SM, Benson M, Meehan RR. Rapid reprogramming of epigenetic and transcriptional profiles in mammalian culture systems, Genome Biol 2015 Feb 4;16:11. doi: 10.1186/s13059-014-0576-y.

40. Houshdaran S, Hawley S, Palmer C, Campan M, Olsen MN, Ventura AP, Knudsen BS, Drescher CW, Urban ND, Brown PO, Laird PW. DNA methylation profiles of ovarian epithelial carcinoma tumors and cell lines. PLoS One 2010; 5:e9359. https://doi:10.1371/journal.pone.0009359.

\section{Publisher's Note}

Springer Nature remains neutral with regard to jurisdictional claims in published maps and institutional affiliations.

Ready to submit your research? Choose BMC and benefit from:

- fast, convenient online submission

- thorough peer review by experienced researchers in your field

- rapid publication on acceptance

- support for research data, including large and complex data types

- gold Open Access which fosters wider collaboration and increased citations

- maximum visibility for your research: over $100 \mathrm{M}$ website views per year

At $\mathrm{BMC}$, research is always in progress.

Learn more biomedcentral.com/submissions 